\title{
AR JUDESIŲ MOKYMASIS PAKEIČIA ŠUOLIO TIKSLUMO PRIKLAUSOMYBĘ NUO POTENCIACIJOS?
}

\author{
Jūratė Kudirkaitė, Albertas Skurvydas, Edita Lingytė, Nerijus Masiulis, Kazimieras Pukẻnas, \\ Vidas Bružas, Viktoras Šilinskas \\ Lietuvos kūno kultūros akademija, Kaunas, Lietuva
} Jūratė Kudirkaitė. Biologijos mokslo krypties doktorantė. Lietuvos kūno kultūros akademijos Lengvosios atletikos katedros asistentė.
Mokslinių tyrimų kryptis — motorinès sistemos kompleksinè ir dinaminė adaptacija.

\section{SANTRAUKA}

Duomenu, kaip mokymasis veikia judesiu tiksluma, rasti galima, tačiau visai nèra žinoma, kaip nervu ir raumenu sistemos (NRS) potenciacija paveiks šuolio atlikimo tikslumo rodiklius. Tyrimo tikslas — nustatyti, ar judesiu mokymasis pakeičia šuolio tikslumo priklausomybę nuo potenciacijos. Siekdami užsibrěžto tikslo, stengemès atsakyti $i$ šiuos klausimus: 1) ar NRS potenciacija pakeičia maksimalu šuolio aukštį?? 2) ar NRS potenciacija pakeičia šuolio atlikimo tikslumq ir kaituma? 3) ar 9 mokymosi pratybos pakeičia tiksluma ir kaituma? 4) ar išmokto judesio atlikimo tikslumas ir kaitumas mažiau priklauso nuo potenciacijos?

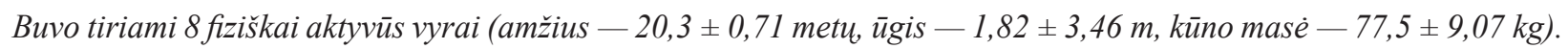
Tiriamieji po 10 min lèto bégimo pramankštos atliko vertikalius šuolius iš vietos ant KISTLER plokštès. Po triju maksimalaus aukščio šuoliu buvo apskaičiuojamas kiekvieno tiriamojo 30\% maksimalaus aukščio šuolis (tikslumo šuolis). Pailsèję 5 min, tiriamieji atliko tikslumo šuolius tol, kol pasieke reikiama šuolio aukští, ir jiems buvo suteikiama grižtamoji informacija (GI), tada turèjo atlikti dar 20 šuoliu nesuteikiant GI. Po šiu šuoliujiems buvo skiriamas potenciacija sukeliantis krūvis (PK), o pailsèjus 1 min vèl atliekama 20 šuoliu be GI. Tas pats tyrimas pakartotas po devyneriu šuolio tikslumo mokymosi pratybu.

Nustatyta, kad 9 mokymosi pratybos ir PK padidino šuolio maksimalaus aukščio rodiklius $(p<0,05)$. Manome, kad vertikalaus šuolio aukščio rodikliai po mokymosi padidejo ne dèl raumenu, bet dèl nervu sistemos adaptacijos, kitaip tariant dèl to, kad CNS išmoko tiksliau valdyti šuolio metu dalyvaujančius raumenis. Taip pat po mokymosi sumažejo absoliučiu ir kaitumo klaidu dydis (p < 0,05). Vadinasi, po mokymosi tiriamieji atliko tikslesnius ir stabilesnius šuolius. PK prieš mokymasi padidino absoliučiu ir kaitumo klaidu dydi ( $<<0,05)$, o po mokymosi neturèjo įtakos šiems tikslumo rodikliams ( $p>0,05)$. Manome, kad po mokymosi tiriamieji adaptavosi prie potenciacijos sukeltu NRS pokyčiu. Visa tai rodo, kaip mokantis tiksliai atlikti šuolius smegenyse susidaro vidiniai modeliai, kurie leidžia atlikti šuolius tiksliau ir stabiliau.

Raktažodžiai: centrine nervu sistema, šuoliu tikslumas ir kaitumas, potenciacija, vidiniai modeliai, mokymasis.

\section{IVADAS}

$\check{Z}$ mogaus judesiu atlikimo tikslumas priklauso nuo išmokimo, motorinès atminties, raumenų koordinacijos, laiko ir erdvès pojūčio (Goodbody \& Wolpert, 1998), judesio sudètingumo ir kt. (Shadmehr \& Moussavi, 2000). Svarbus judesiu valdymo veiksnys yra gebejjimas jau išmoktus judesius atlikti esant naujoms, nuolat kintančioms sąlygoms, priešingoms nei jie buvo išmokti (Reynolds \& Bronstein, 2003). Judesių mokymosi metu yra sukuriama motorine programa, nuo kurios sudarymo tikslumo priklauso agonistu, sinergetų, antagonistu, rankų ir kojų raumenu koordinacija, kuri padeda geriau atlikti šuolị (Schmidt, 1988; Skurvydas ir kt., 1988). Nors galima rasti duomenų, kaip mokymasis veikia judesių tikslumą ir kad kojų raumenų potenciacija padidina maksimalų šuolio aukštit, tačiau visai nèra žinoma, kaip nervų ir raumenų sistemos (NRS) potenciacija veikia šuolio atlikimo tikslumo rodiklius.

Tyrimo tikslas - nustatyti, ar judesių mokymasis pakeičia šuolio tikslumo priklausomybę nuo potenciacijos.

Hipotezès: a) mokymasis sumažins kaitumo ir absoliučių klaidų dydị; b) nervų ir raumenų sistemos (NRS) potenciacija padidins kaitumo ir 
absoliučiu klaidų dydị; c) mokymasis sumažins potenciacijos poveikị kaitumo ir absoliučiu klaidu dydžiui.

Siekdami užsibrèžto tikslo, stengèmès atsakyti i šiuos klausimus: 1) ar NRS potenciacija pakeičia maksimalų šuolio aukštị? 2) ar NRS potenciacija pakeičia šuolio atlikimo tikslumą ir kaitumą? 3) ar 9 mokymosi pratybos pakeičia tikslumą ir kaitumą? 4) ar išmokto judesio atlikimo tikslumas ir kaitumas mažiau priklauso nuo potenciacijos?

\section{TYRIMO METODAI IR ORGANIZAVIMAS}

Buvo tiriami 8 jauni fiziškai aktyvūs vyrai (amžius - 20,3 $\pm 0,71$ metŭ, ūgis $-1,82 \pm 3,46 \mathrm{~m}$, kūno masè $-77,5 \pm 9,07 \mathrm{~kg}$ ). Tiriamieji 4 dienas prieš tyrimą buvo supažindinami su būsimo eksperimento eiga.

Šoklumo testavimas. Tiriamieji po $10 \mathrm{mi}-$ nučiu lèto bégimo (110-120 tv. / min) atliko vertikalius šuolius, amortizuojamai pritūpdami per kelių sąnarius iki $90^{\circ}$ kampo, liemuo - vertikalios padèties, rankos ant klubų. Šuoliai buvo atliekami ant KISTLER plokštès (BioWare Performance Software Version 3.0 Type 2812A2-3. Operating Instruction. Kistler Instrumente AG Winterthur).

Kojų raumenų jègos nustatymas. Tiriamajam reikejo pritūpti $90^{\circ} \mathrm{kampu}$ ir atsistoti laikant ant pečių maksimalaus svorio štangą (su Smito staklèmis). Tiriamiesiems iš pradžių buvo skiriamas $40-60 \%$ maksimaliosios kojų raumenų jègos svoris. Pailsejjus $1 \mathrm{~min}$ ir po raumenu tempimo pratimu jau buvo skiriamas $60-80 \%$ maksimalios jègos svoris. Tada poilsis tarp bandymų buvo pailgintas iki 5 min tam, kad tiriamasis prieš kiekvieną bandymą būtų visiškai atsigavęs. Svoris buvo didinamas tol, kol tiriamasis jau nebegalėdavo su juo atsistoti.

Kojų raumenų potenciacija. Per kelius pritūpus iki $90^{\circ} \mathrm{kampo}$, raumuo du kartus po $10 \mathrm{~s}$ (kas 30 s pailsint) izometriškai išugdydavo 70\% maksimaliosios kojų raumenu jẻgos intensyvumą. Tiriamieji po potenciaciją sukeliančio krūvio (PK) pailsèję 1 min (P), atliko 3 maksimalaus aukščio šuolius.

Tyrimo eiga. Tiriamieji prieš krūvị atlikdavo pramankštą 10 min lètai bègdami. Tada buvo nustatoma jų maksimalioji kojų raumenu jèga $(111,9 \pm 31,73 \mathrm{~kg})$. Tiriamiesiems pailsèjus 4 dienas, buvo atliekami tolesni tyrimai. Prieš krūvį tiriamieji vèl $10 \mathrm{~min}$ lètai bègo (110-120 tv. / $\mathrm{min})$. Atlikus 3 maks. aukščio šuolius, buvo apskaičiuojamas kiekvieno tiriamojo 30\% maks. aukščio šuolis. Po 5 min poilsio tiriamieji atlikdavo kelis $30 \%$ maks. aukščio šuolius, suteikiant jiems grižtamają informaciją (GI) tol, kol jie pasiekdavo reikiamą šuolio aukšti, tada atlikdavo 20 šuolių be GI. Po šuolių buvo atliekamas kojų raumenų PK. Prieš ir po PK praejjus $1 \mathrm{~min}$, jie kas $5 \mathrm{~s}$ atlikdavo
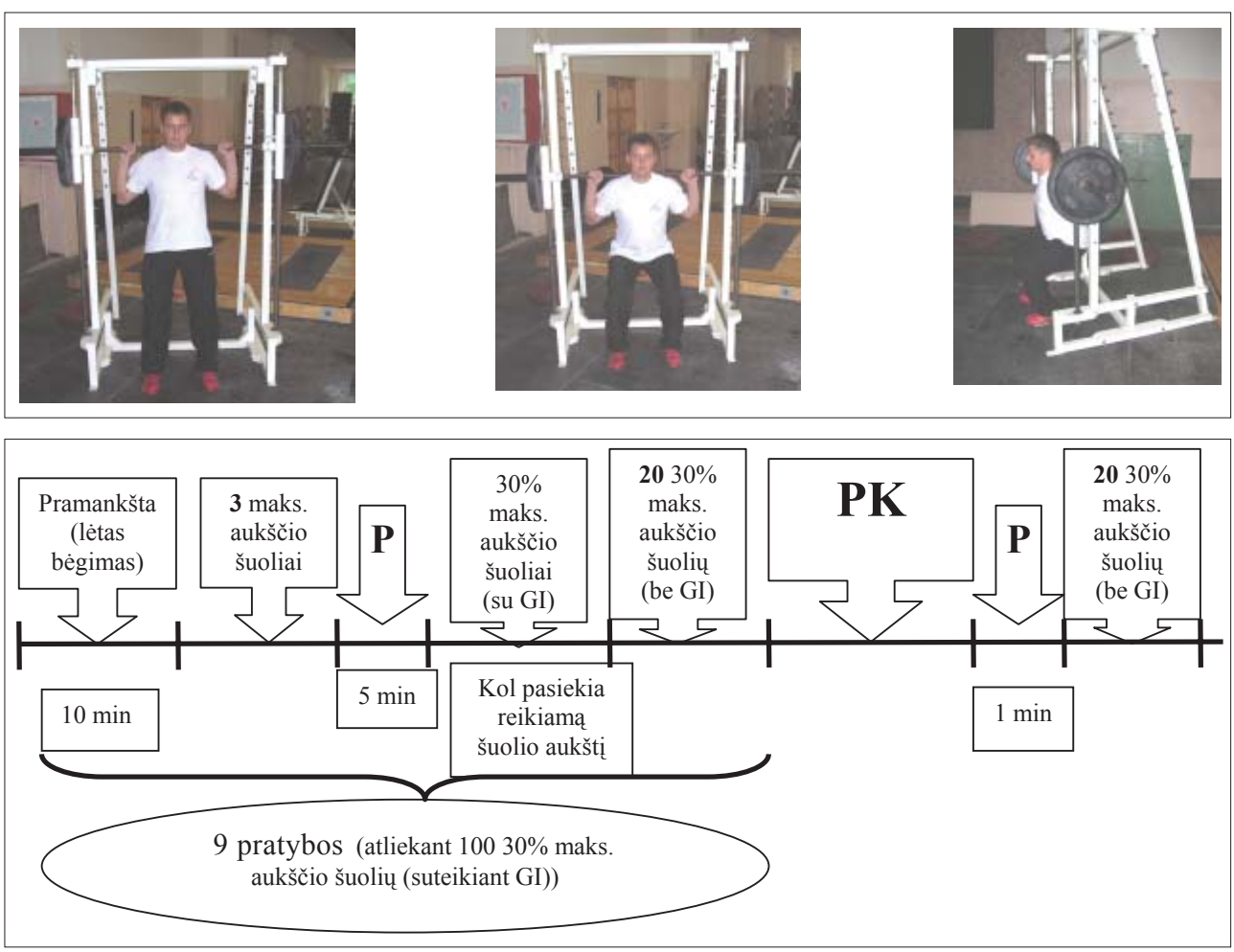

1 pav. Maksimaliosios kojų raumenų jègos nustatymas

2 pav. Šuolio tikslumo nustatymo protokolas 


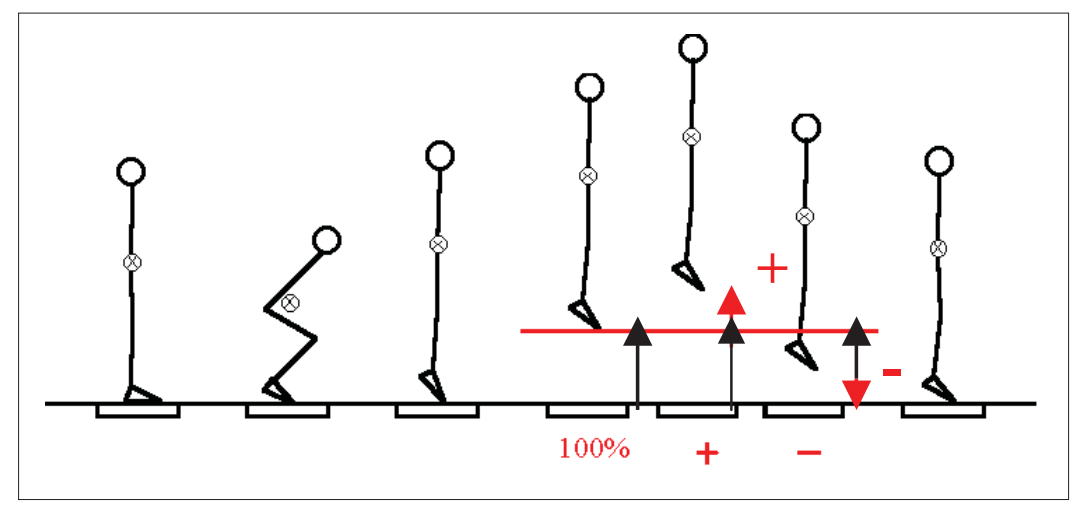

20 šuolių, kuriu aukštis sieke 30\% maksimalaus. Tiriamieji šuolius atliko nesuteikiant jiems GI, t. y. nebuvo pasakomas atlikto šuolio aukštis (2 pav.).

Tie patys tiriamieji per 9 pratybas mokèsi tiksliai atlikti šuolius, per vienerias padarydami po 100 30\% maksimalaus aukščio šuoliu, suteikiant GI. Visas tyrimas su PK pakartotas po 9 mokymosi pratybu.

Šuolio tikslumui įvertinti buvo apskaičiuojamos absoliučios, konstantinès ir kaitumo klaidos (Schmidt, Lee, 1999; Magill, 2006).

Absoliučios klaidos suteikia informacijos apie jų dydị ir apskaičiuojamos pagal formulę:

Absoliuti klaida $=\sum\left|x_{i}-T\right| / n$,

čia $\mathrm{x}_{\mathrm{i}}$ - atliktas šuolis $(\mathrm{cm})$;

$\mathrm{T}$ - taikinio dydis, t. y. reikiamas šuolio aukštis (30\% maks.);

$\mathrm{n}$ - bandymų skaičius (20 šuoliu);

vertikalūs skliausteliai (II) reiškia, kad vidurkis buvo apskaičiuojamas nekreipiant demesio $\mathfrak{i}$ algebrinius ženklus (+ / -).

Absoliučios klaidos rodo absoliutų nuokrypi nuo reikiamo šuolio aukščio. Pavyzdžiui: jei tiriamajam reikejjo pašokti $30 \%$ maks. aukščio $12 \mathrm{~cm}$, o jis pašoko $14,5 \mathrm{~cm}$ - tai absoliutus nuokrypis lygus $2,5 \mathrm{~cm}$, jei pašoko $9 \mathrm{~cm}$ - tai absoliutus nuokrypis lygus $3 \mathrm{~cm}$. Apskaičiuojant absoliučias klaidas, nebuvo kreipiamas demesys $\mathfrak{i}$ algebrinius ženklus (+ / -).

Konstantinès klaidos rodo šuoliu atlikimo nesimetriškumo tendenciją. Šios klaidos buvo apskaičiuojamos pagal formulę (Schmidt, Lee, 1999; Magill, 2006):

Konstantinè klaida $=\Sigma\left(\mathrm{x}_{\mathrm{i}}-\mathrm{T}\right) / \mathrm{n}$

Apskaičiuojant konstantinių klaidų dydį, buvo kreipiamas dèmesys $\mathfrak{i}$ algebrinius ženklus $(+/-)$, t. y. žiūrima, kiek tiriamasis pašoko aukščiau ar žemiau, nei jam reikejo (3 pav.). Pavyzdžiui: jei tiriamasis pašoko aukščiau, nei jam reikèjo - tai nuokrypio reikšmès buvo teigiamos $(+)$, o jei žemiau - neigiamos (-), t. y. jei tiriamajam reikejjo pašokti $30 \%$ maks. aukščio $12 \mathrm{~cm}$, o jis pašoko $14,5 \mathrm{~cm}$ - tai absoliutus nuokrypis lygus $+2,5 \mathrm{~cm}$, jei pašoko $9 \mathrm{~cm}-$ absoliutus nuokrypis lygus $-3 \mathrm{~cm}$.

Kaitumo klaidos buvo apskaičiuojamos pagal formulę:

$$
\text { Kaitumo klaida }=\sqrt{\sum\left(x_{i}-M\right)^{2} / n},
$$

čia $\mathrm{M}$ - atliktų šuolių vidurkis $(\mathrm{cm})$.

Jos rodo šuolių atlikimo kaitumą, nesuderinamumą, arba atvirkščiai, judesių atlikimo nuoseklumą, stabilumą (Schmidt, Lee, 1999; Magill, 2006).

Matematinė statistika. Išanalizavus tyrimo duomenis, apskaičiuotas aritmetinis rezultatų vidurkis (), vidutinis standartinis nuokrypis (s), skirtumo tarp vidurkiu statistinis patikimumas (p), procentinè rezultatų kaita. Skirtumo tarp aritmetinių vidurkių reikšmingumas nustatytas pagal dvipusį nepriklausomų imčių Stjudento t kriterijų. Skirtingų veiksnių (mokymosi ir potenciacijos) rezultatu reikšmingumui įvertinti taikème dviejų veiksnių dispersinę analizę (SPSS programų paketu). Skirtumas statistiškai reikšmingas, kai $\mathrm{p}<0,05$.

\section{REZULTATAI}

Maksimalaus šuolio aukščio kaita: mokymasis ir potenciacija. Devynerios šuolio tikslumo mokymosi pratybos statistiškai reikšmingai pagerino tiriamujų maksimalaus šuolio aukščio rodiklius $(p=0,04)$. Tiriamieji po mokymosi pašoko $5,70 \mathrm{~cm}$ aukščiau nei prieš ji (nuo 39,6 \pm 6,04 iki $45,3 \pm 6,52 \mathrm{~cm})$ (4 pav.).

Statistiškai reikšmingai padidèjo maksimalaus šuolio aukščio rodikliai ir po kojų raumenų potenciacijos $(\mathrm{p}<0,05)$. Prieš mokymąsi $\mathrm{h}_{\text {maks. }}$ pagerejo nuo $39,6 \pm 6,04$ iki $44,4 \pm 6,52 \mathrm{~cm}$, o kojų raume- 


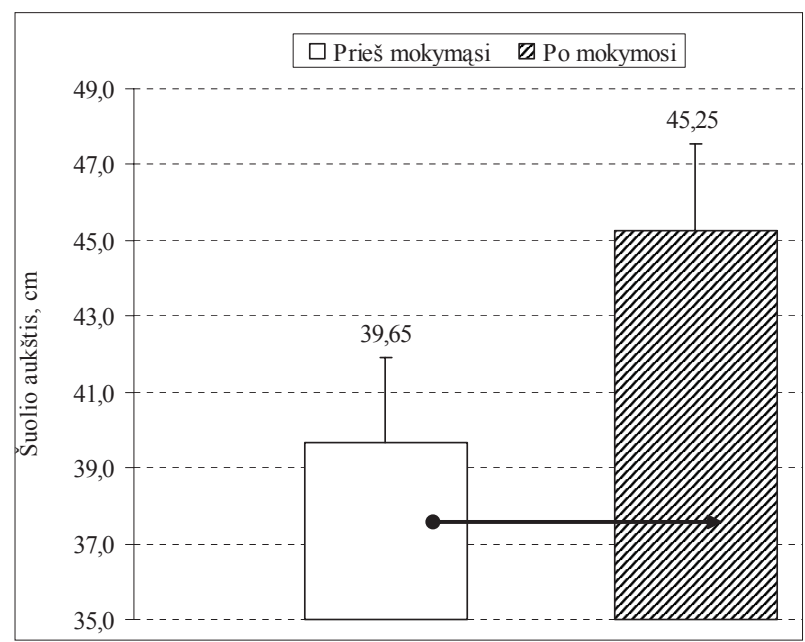

4 pav. Mokymosi poveikis maksimaliam šuolio aukščiui ( $\left.\mathbf{h}_{\text {maks. }}\right)$

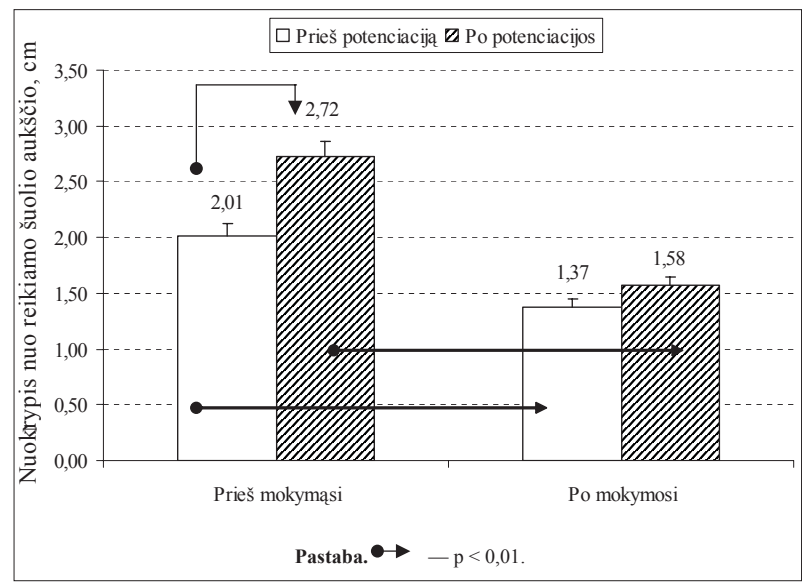

6 pav. Potenciacijos ir mokymosi poveikis absoliučiam tikslumui (absoliučios klaidos)

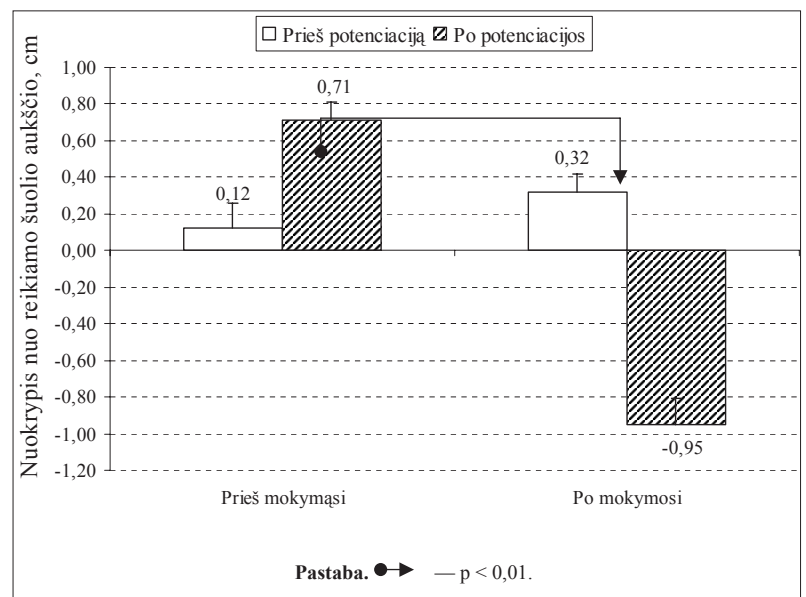

8 pav. Potenciacijos poveikis konstantinių klaidų dydžiui prieš mokymąsi ir po jo

nų potenciacija maksimalų šuolio aukšti padidino nuo $45,3 \pm 5,45$ iki 50,1 $\pm 5,86 \mathrm{~cm}$ (5 pav.).

Šuolių atlikimo tikslumas ir kaitumas: mokymasis ir potenciacija. Absoliučios klaidos rodo, kad po mokymosi statistiškai reikšmingai pagerejjo šuolių atlikimas $(\mathrm{p}=0,000000003)$. Tiriamieji, atlikdami šuolius i aukšti $30 \%$ maksima-

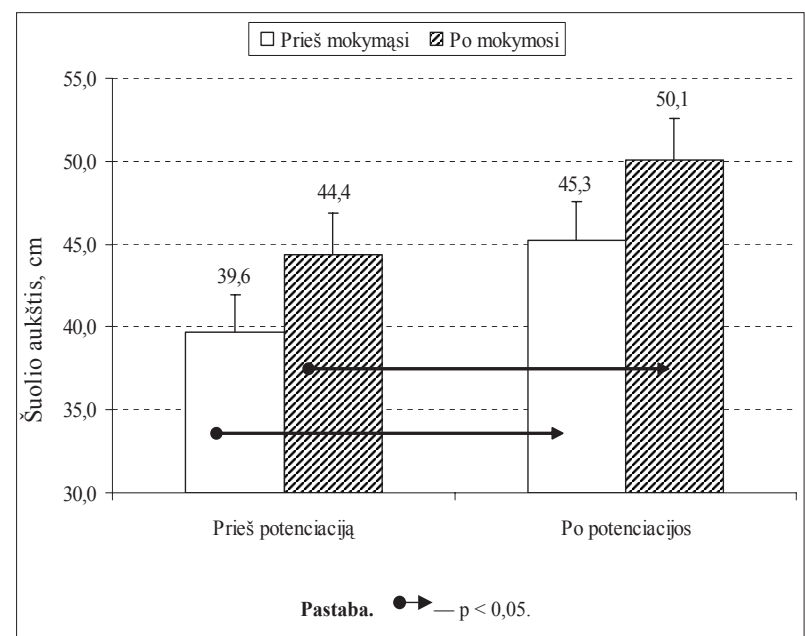

5 pav. NRS potenciacijos poveikis maksimaliam šuolio aukščiui $\left(\mathbf{h}_{\text {maks. }}\right)$

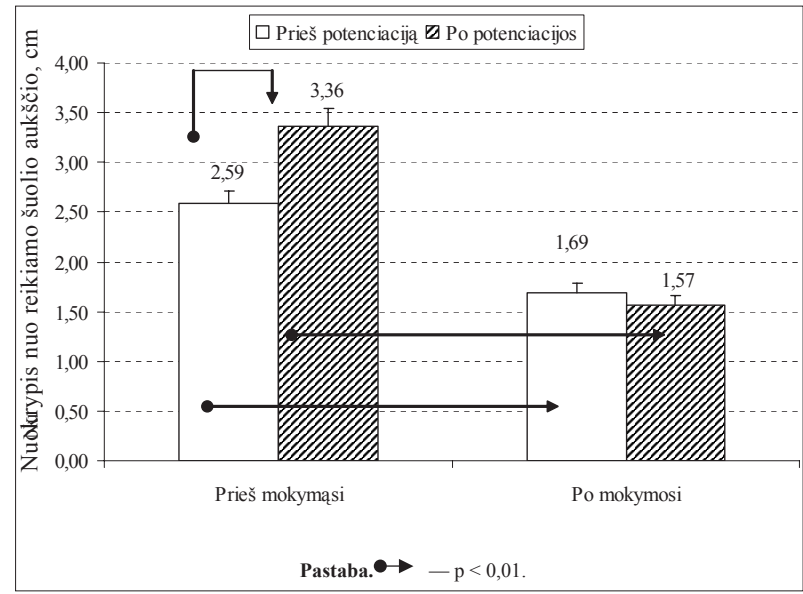

7 pav. Potenciacijos ir mokymosi poveikis klaidoms

liosios jègos intensyvumu, kai pratimas atliekamas be grižtamosios informacijos suteikimo, po mokymosi absoliučių klaidų padarẻ $7 \%$ mažiau. PK statištikai reikšmingai $(\mathrm{p}=0,002)$ padidino prieš mokymąsi atliekamų šuolių absoliučių klaidų dydi, ir tikslumas pablogejo $4 \%$, o po mokymosi dèl kojų raumenų potenciacijos šiek tiek pablogejo atlikimo tikslumas $(0,27 \mathrm{~cm})$, tačiau nenustatėme statistiškai reikšmingo rezultatų skirtumo $(\mathrm{p}>0,05)$. Mokymosi ir potenciacijos sąsaja yra statistiškai reikšminga $(p=0,021) .9$ šuoliu tikslumo mokymosi pratybos sumažino absoliučiu klaidų dydi (6 pav.).

Kaitumo klaidos rodo šuoliu atlikimo kaitumą, arba atvirkščiai, judesių atlikimo nuoseklumą. Kaitumo klaidos priklausomai nuo mokymosi skiriasi statistiškai reikšmingai $(p=0,0000000002)$. Po 9 mokymosi pratybų prieš PK tiriamieji atliko $12 \%$ mažiau kintamus šuolius, taip pat po NRS potenciacijos kaitumo klaidu dydis buvo $7 \%$ mažesnis. Kaitumo klaidos priklausomai nuo NRS potenciacijos skiriasi statistiškai reikšmingai 
Lentelè. Šuolio tikslumo rodiklių koreliacinis ryšys

\begin{tabular}{|c|c|c|}
\hline \multicolumn{3}{|c|}{ Klaidos } \\
\hline Konstantinès & Absoliučios & Kaitumo \\
\hline 0,04 & 0,09 & 0,10 \\
\hline
\end{tabular}

$(\mathrm{p}=0,033)$. Prieš mokymąsi dèl kojų raumenų potenciacijos atsirado daugiau kaitumo klaidų, o po mokymosi PK net sumažino kaitumo klaidas (7 pav.). Mokymosi ir potenciacijos sąsaja yra statistiškai reikšminga $(p=0,005)$.

Konstantines klaidos rodo, kad po PK prieš mokymąsi tiriamieji pašoko aukščiau, nei jiems reikèjo $(0,71 \pm 0,43 \mathrm{~cm})$, o po jo pašoko žemiau $(-0,95 \pm 0,65 \mathrm{~cm})$. Konstantinès klaidos priklausomai nuo mokymosi statistiškai reikšmingai nesiskyre $(p>0,05)$. NRS potenciacija statistiškai reikšmingai pakeite konstantiniu klaidu dydi $(\mathrm{p}=0,02)$ (8 pav.). Mokymosi ir potenciacijos sąsaja yra statistiškai reikšminga $(\mathrm{p}=0,00000005)$.

Tiriamujų šuolio į aukšti absoliučių, kaitumo ir konstantinių klaidų dydžio prieš mokymąsi ir po jo koreliacinis ryšys yra labai silpnas (atitinkamai $0,09,0,10$ ir 0,04), todèl negalima prognozuoti, kaip mokymasis paveiks šių klaidų dydi (žr. lent.). Prieš mokymąsi išanalizavus tiksliausiai $(1,16 \pm 0,98 \mathrm{~cm})$ ir netiksliausiai atliekančio tiriamojo $(4,04 \pm 1,82 \mathrm{~cm})$ šuolių absoliučių klaidų dydị matyti, kad vieno iš aštuonių tiriamujų, prieš mokymąsi tiksliausiai atlikusio šuolius, po mokymosi absoliučių klaidų dydis buvo jau beveik didžiausias - septintas iš aštuonių tiriamujuc $(1,47 \pm 0,73 \mathrm{~cm})$. Tiriamasis, prieš mokymąsi blogiausiai atlikęs šuolius, po mokymosi sumažino absoliučių klaidų dydị iki $0,76 \pm 0,76 \mathrm{~cm}$ ir buvo šeštas pagal ši tikslumo rodiklį.

\section{REZULTATŲ APTARIMAS}

Tyrimo duomenys patvirtino iškeltas hipotezes: a) mokymasis sumažino kaitumo ir absoliučių klaidų dydi; b) NRS potenciacija padidino kaitumo ir absoliučiu klaidų dydį; c) mokymasis sumažino potenciacijos poveiki kaitumo ir absoliučių klaidų dydžiui.

Mūsų žiniomis, tai yra pirmas tyrimas, irodantis, kaip NRS potenciacija bei mokymasis atskirai ir kartu veikia šuolių atlikimo tikslumą (t. y. absoliučių, kaitumo ir konstantiniu klaidų dydi). Neteko aptikti panašių tyrimų, nagrinėjančių, kaip potenciacija veikia judesių tikslumą ir kaitumą.

Nors tiriamieji turejo stengtis atlikti kuo tikslesnius šuolius, tačiau po devynerių tikslumo mo- kymosi pratybų pagerejo ir tiriamujų maksimalus šuolio aukštis $\left(\mathrm{h}_{\text {maks }}\right)$. Yra nustatyta, kad net per kelerias šoklumo pratybas padideja valinga raumenu jèga, nes išmokstama geriau atlikti judesi (Schmidt, 1988). Taip pat autoriai teigia, kad dèl per šoklumo pratybas ívykusios nervų ir raumenų sistemos adaptacijos, dèl raumenų antagonistu slopinimo padidejjimo ir dèl geresnès sinergetu aktyvacijos padideja vertikalus šuolio aukštis (Komi, 1984; Lyttle et al., 1996). Mokslininkai yra nustatę, kad tiek 6 (Rahimi \& Behpur, 2005), tiek 4 ar 7 savaičiu (et al., 2003) trukmès šuoliu pratybos akivaizdžiai pagerina vertikalaus šuolio aukščio rodiklius. Mes manome, kad vertikalaus šuolio aukštis padidejjo ne dèl raumenų, bet dèl nervu sistemos adaptacijos, kitaip tariant dèl to, kad CNS išmoko tiksliau valdyti šuolio metu dalyvaujančius raumenis.

Ne tik mokymasis, bet ir NRS potenciacija pagerino tiriamujų maksimalų šuolio aukšti. Valingo raumenų darbo metu sukelta potenciacija vadinama postaktyvacine potenciacija (PAP) ir gali būti sukelta tiek dinaminio, tiek izometrinio krūvio metu (Gullich \& Schmidtbleicher, 1996; Young et al., 1998; Chiu et al., 2003). Pastebèta, kad PAP po izometrinio ar dinaminio stimulo pagreitina jègos išugdymą, šuolio aukšti ir važiuojant sprinto dviračiu pasiektą rezultatą (Gullich \& Schmidtbleicher, 1996; Young et al., 1998; Abbate et al., 2000). Yra žinoma, kad po bet kokio tipo raumens susitraukimo, pasireiškia postaktyvacinès potenciacijos mechanizmas, t. $y$. lengvuju miozino grandžių fosforilinimas, kuris padidina miofilamentų jautrumą $\mathrm{Ca}^{2+}$ (MacIntosh, 2003), dèl to padideja miozino skersinių tiltelių aktyvumas $\mathrm{Ca}^{2+}$. D. G. Sale (2004) teigia, kad po submaksimalaus raumenų susitraukimo padidèja motorinių vienetų jègos atsakas. Remdamiesi daugelio mokslininkų duomenimis (Abbate et. al., 2000; MacIntosh, 2003; Sale, 2004), galime teigti, kad postaktyvacinè potenciacija padidina motorinių vienetų aktyvumą ir miozino skersinių tilteliu jautrumą $\mathrm{Ca}^{2+}$, kartu padidindama tiriamujų vertikalaus šuolio aukščio rodiklius.

Atlikto tyrimo metu tiriamieji turèjo 9 šuoliu tikslumo mokymosi pratybas, po kuriu sumažèjo absoliučių klaidų dydis. Kaip teigia D. C. Quesada ir R. A. Schmidt (1970), absoliučių klaidų 
vidurkis sumažèja po judesio treniravimo. Manome, kad šuoliui išmokti užteko 9 pratybų, po kurių tiriamieji jau tiksliau atliko šuolius. Taip pat mokymasis sumažino kaitumo klaidų dydi tiek prieš NRS potenciaciją, tiek po jos. İdomu tai, kad išmokto judesio kaitumo klaidų dydis po potenciacijos net sumažèjo, o prieš mokymąsi kojų raumenų potenciacija smarkiai padidino kaitumą. Mažesnį kaitumo klaidų dydi po mokymosi, manytume, lemia tai, kad tiriamieji išmoko atlikti tikslius šuolius ir, kaip teigia A. M. Newel ir D. M. Corcos (1993), po mokymosi sumažeja judesiu atlikimo kaitumas, kuris dažnai suprantamas kaip sensomotorinès sistemos stabilumo rodiklis. Remiantis mūsų gautais duomenimis, mokymasis pagerino šuolių atlikimo nuoseklumą ir tiriamieji atliko mažiau kaičius šuolius. Tai paaiškina A. M. Newell ir D. M. Corcos (1993) teiginys, kad rodiklių kaitumas sumažeja dèl motorinio igūdžio išmokimo. Taip pat R. J. Beers su bendraautoriais (2004) teigia, kad kuo mažesnis judesio kaitumas, tuo judesys tikslesnis.

Kojų raumenų potenciacija skirtingai veikè konstantines šuolių atlikimo klaidas prieš mokymąsi ir po jo. Konstantinès klaidos rodo judesio atlikimo nesimetriškumą (Magill, 2006). Prieš mokymąsi po NRS potenciacijos tiriamieji šoko aukščiau, nei jiems reikejo, t. y. konstantinès klaidos buvo teigiamos $(+)$, o po mokymosi konstantinių klaidų vidurkis parodè, kad tiriamieji šoko žemiau, negu jiems reikejo (-). Galima teigti, kad kojų raumenų postaktyvacinè potenciacija skirtingai veikia išmoktą ir neišmoktą judesị.

Dèl NRS potenciacijos prieš mokymąsi pastebėtas didelis šuolių tikslumo pablogèjimas, o toki organizmo atsaką gali patvirtinti teiginys, kad organizmo pokyčiai atliekant užduoti yra nenuspejjami - žmogus negali iš anksto tiksliai susikurti savo motorinès programos (Wolpert et al., 2001). Nuo motorinès programos sudarymo tikslumo priklauso agonistu, sinergetu, antagonistų, rankų ir kojų raumenų koordinacija, kuri padeda geriau atlikti šuoli (Schmidt, 1988; Skurvydas ir kt., 1988). Tačiau jau po 9 tikslumo mokymosi pratybu kojų raumenu potenciacija nepakeite $30 \%$ maksimalaus aukščio šuolio atlikimo tikslumo. Manome, kad per 9 pratybas buvo sukurta tikslesné motoriné programa, kurios jau neveiké NRS potenciacija.

Po ilgo mokymosi žmonès yra pajègūs prisitaikyti prie dideliu regos (Flanagan, Rao, 1995; Imamizu, Shimojo, 1995; Imamizu et al., 1995;
Ghahramani, Wolpert, 1997) ir raumenyno (Conditt et al., 1997; Flanagan, Wing, 1997; Sheidt et al., 1997) pokyčių. Po mokymosi tiriamieji adaptavosi prie potenciacijos sukeltų NRS pokyčių, kurie neturejjo itakos šuoliu atlikimo absoliučiam ir kintamam tikslumui.

Žmogaus smegenų motorinëje žievèje po mokymosi susidarę vidiniai modeliai leidžia prisitaikyti prie naujos dinamiškos aplinkos. Vidiniai modeliai - tai mechanizmai, pagal kuriuos CNS valdo jègos jutima, leidžianti atlikti judesi. Kaip teigia R. L. Sainburg su bendraautoriais (1999), mokantis naujo judesio, CNS pamažu suformuoja dinaminès aplinkos vidini vaizdą - vidinị modelị. Taigi, remdamiesi šių mokslininkų duomenimis, galime teigti, kad po 9 pratybų smegenyse susidare vidiniai modeliai, kurie po mokymosi ir koju raumenu potenciacijos leido tiksliau atlikti $30 \%$ maksimalaus aukščio šuolius. Todèl NRS potenciacija po mokymosi neturejo įtakos judesių tikslumui bei kaitumui, t. y. šuolių atlikimo absoliučių ir kaitumo klaidų dydžiui.

Tyrimo rezultatai parodè, kad absoliučių, kaitumo ir konstantinių klaidų dydžio prieš mokymąsi ir po jo koreliacinis ryšys yra labai silpnas. Vadinasi, iš pirminių šuolių atlikimo duomenų negalima prognozuoti, kaip po mokymosi tiriamieji atliks 30\% maksimalaus aukščio šuolius be GI. Kaip teigia E. Rudas su bendraautoriais (2006), iš tyrimo pradžioje nustatytų vertikalių šuolių rodiklių negalime prognozuoti būsimų rezultatų. Tai rodo, kad motorinès sistemos adaptacija yra kompleksiška, dinamiška ir netiesinè, t. y. sunkiai numanoma bei prognozuojama.

\section{IŠVADOS}

1. Devynerios mokymosi pratybos ir NRS potenciacija reikšmingai pagerino maksimalų šuolio aukštit.

2. Devynerios mokymosi pratybos statistiškai reikšmingai sumažino šuolių atlikimo absoliučių ir kaitumo klaidų dydị, t. y. po mokymosi pagerejjo tikslumas ir sumažèjo kaitumas.

3. Nervų ir raumenų sistemos potenciacija prieš mokymąsi padidino šuolių atlikimo absoliučiu ir kaitumo klaidų dydi, tačiau po mokymosi neturèjo joms itakos.

4. Mokantis tiksliai atlikti šuolius, smegenyse susidaro vidiniai modeliai, kurie leidžia atlikti šuolius tiksliau ir stabiliau. 


\section{LITERATŪRA}

Abbate, F., Sargeant, A. J., Verdijk, P. W. et al. (2000). Effects of high frequency initial pulses and posttetanic potentiation on power output of skeletal muscle. Journal of Applied Physiology, 88, 1, 35-40.

Beers, R. J., Haggard, P., Wolpert, D. M. (2004). The role of execution noise in movement variability. Journal of Neurophysiology, 91, 1050-1063.

Chiu, L. Z. F., Fry, A. C., Weiss, L. W. et al. (2003). Postactivation potentiation response in athletic and recreationally trained individuals. Journal of Strength and Conditioning Research, 17 (4), 671-677.

Conditt, M. A., Gandolfo, F., Mussa-Ivaldi, F. A. (1997). The motor system does not learn the dynamics of the arm by rote memorization of past experience. Journal of Neurophysiology, 78, 554-560.

Flanagan, J. R., Rao, A. K. (1995). Trajectory adaptation to a nonlinear visuomotor transformation: Evidence for motion planning in visually perceived space. Journal of Neurophysiology, 74, 2174-2178.

Flanagan, J. R., Wing, A. M. (1997). The role of internal models in motor planning and control: Evidence from grip force adjustments during movements of hand-held loads. Journal of Neuroscience, 17, 1519-1528.

Ghahramani, Z., Wolpert, D. M. (1997). Modular decomposition in visuomotor learning. Nature, 386, 392-395.

Goodbody, S. J., Wolpert, D. M. (1998). Temporal and amplitude generalization in motor learning. Journal of Neurophysiology, 79, 1825-1838.

Gullich, A., Schmidtbleicher, D. (1996). MVC-induced short-term potentiation of explosive force. New Stud Athletics, 11, 67-81.

Imamizu, H., Shimojo, S. (1995). The locus of visual-motor learning at the task or manipulator level: Implications from intermanual transfer. Journal of Experimental Psychology: Human Perception Performance, 21, 719-733.

Imamizu, H., Uno, Y., Kawato, M. (1995). Internal representations of the motor apparatus: Implications from generalization in visuomotor learning. Journal of Experimental Psychology: Human Perception Performance, 21, 1174-1198.

Komi, P. V. (1984). Physiological and biomechanical correlates of muscle function: Effects of muscle structure and stretch-shortening cycle on force and speed. Exercise and Sport Sciences Reviews, 12, 81-121.

Luebbers, P. E., Potteiger, J. A., Hulver, M. W. et al. (2003). Effects of plyometric training and recovery on vertical jump performance and anaerobic power. Prieiga per interneta: PMID: 14636088 [PubMed - indexed for MEDLINE]

Lyttle, A. D., Wilson, G. J. \& Ostrowski, K. J. (1996). Enhancing performance: Maximal power versus combined weights and plyometrics training. Journal of Strength Conditioning Research, 10, 173-179.

MacIntosh, B. R. (2003). Role of calcium sensitivity modulation in skeletal muscle performance. News of Physiology Science, 18, 222-225.

Magill, R. A. (2006). Motor Learning and Control: Concepts and Applications. McGraw-Hill International edition.
Newell, A. M., Corcos, D. M. (1993). Variability and Motor Control. Human Kinetics Publishers.

Quesada, D. C., Schmidt, R. A. (1970). A test of the Adams-Creamer decay hypothesis for the timing of motor responses. Journal of Motor Behavior, 2, 273-283.

Rahimi, R. and Behpur, N. (2005). The effects of plyometric, weight and pliometric-weight training on anaerobic power and muscular strength. Physical Education and Sport, Vol. 3, 1, 81-91.

Reynolds, R. F., Bronstein, A. M. (2003). The moving platform aftereffect: Limited generalization of a locomotor adaptation. Journal of Neurophysiology, 91, 92-100.

Rudas, E., Skurvydas, A., Mickevičienè, D., Bulotienė, D. (2006). Mergaičiu ir berniukų šoklumo kaita. Ugdymas. Küno kultūra. Sportas, 1, 56-62.

Sainburg, R. L., Ghez, C., Kalakanis, D. (1999). Intersegmental dynamics are controlled by sequential anticipatory, error correction, and postural mechanisms. The American Physiological Society.

Sale, D. G. (2004). Postactivation potentiation: Role in human performance. Exercise and Sport Sciences Reviews, $30,138-143$.

Schmidt, R. A., Lee, T. D. (1999). Motor Control and Learning: A Behavioral Emphasis. Human kinetics.

Schmidt, R. A. (1988). Motor Control and Motor Learning. Champaign, IL: Human Kinetics.

Shadmehr, R., Moussavi, Z. M. (2000). Spatial generalization from learning dynamics of reaching movements. Journal of Neuroscience, 20, 7807-7815.

Sheidt, R. A., Conditt, M. A., Reinkensmeyer, D. J., Mussa-Ivaldi, F. A. (1997). Motor adaptation persists in the absence of kinematic errors. Society for Neuroscience Abstracts, 23 (85), 4.

Skurvydas, A., Stasiulis, A., Vilčinskas, P. (1988). Šoklumo fiziologiniai pagrindai. Vilnius.

Wolpert, D. M., Ghahramani, Z. and Flangan, J. R. (2001). Perspectives and problems in motor learning. TRENDS in Cognitive Sciences, Vol. 5, 11, 487.

Young, W. B., Jenner, A., Griffiths, K. (1998). Acute enhancement of power performance from heavy load squats. Journal of Strength and Conditioning Research, 12 (2), 82-88. 


\title{
DOES MOVEMENT LEARNING CHANGE THE DEPENDENCE OF POTENTIATION ON JUMPING ACCURACY?
}

\author{
Jūratė Kudirkaitė, Albertas Skurvydas, Edita Lingytė, Nerijus Masiulis, \\ Kazimieras Pukėnas, Vidas Bružas, Viktoras Silinskas \\ Lithuanian Academy of Physical Education, Kaunas, Lithuania
}

\begin{abstract}
The aim of this research was to determine if movement learning changed the dependence of potentiation on jumping accuracy. In this study we tried to answer the following questions: 1) does neuro-muscle potentiation change the height of maximum jump? 2) does neuro-muscle potentiation change the accuracy and the variability of jumps? 3) do 9 series of drills change the accuracy and the variability of jumps? 4) do the accuracy and the variability of learnt jumps depend on potentiation less?

The subjects were healthy, physically active men $(\mathrm{n}=8)($ age $-21.3 \pm 0.80$ years, height $1.80 \pm 3.67 \mathrm{~m}$, weight $-77.7 \pm 9.07 \mathrm{~kg}$ and maximal leg muscular strength $-110.0 \pm 30.65 \mathrm{~kg}$ ). After 10 min of warming - up (slow running) the subjects performed standing vertical jumps on a Kistler platform. After three trial jumps the maximum height jump was determined and the jumping load of $30 \%$ maximum height was assigned ("accuracy jumps"). After 5 min rest the subjects performed "accuracy jumps" with feedback information (FI) of the jump height achieved when they reached the proper height and at a dash the subjects performed 20 jumps without FI. After these jumps a potentiation load (PL) was imposed, and after 1 min rest 20 jumps without FI were repeated. The same research protocol was repeated after 9 training series of "accuracy jumps".

It was found that the 9 "accuracy jumps" training series and PL increased the height of vertical jumps $(\mathrm{p}<0.05)$. We think that the increase of vertical jump was due to CNS adaptation. After learning the number of absolute and variable errors significantly decreased $(p<0.05)$, and the implication is that the subjects performed the jumps more accurately and steadily.

Before learning PL, increased the magnitude of absolute and variable errors $(\mathrm{p}<0.05)$, but after learning PL did not impact the accuracy indexes $(\mathrm{p}>0.05)$. We think that after learning the subjects adapted to PL changes. We suggest that learning jumps forms internal models in our brain.
\end{abstract}

Keywords: central nervous system, accuracy and variability of jumps, potentiation, internal models, learning.

Gauta 2006 m. gruodžio 6 d.

Received on December 6, 2006

Priimta $2007 \mathrm{~m}$. vasario $13 \mathrm{~d}$.

Accepted on February 13, 2007
Jūratė Kudirkaitè

Lietuvos kūno kultūros akademija

(Lithuanian Academy of Physical Education)

Sporto g. 6, LT-44221 Kaunas

Lietuva (Lithuania)

Tel +37068626255

E-mail jkudirkaite@lkka.lt 